\title{
Do declines in occupational physical activity contribute to population gains in body mass index? Tromsø Study 1974-2016
}

\author{
Edvard H Sagelv (D) ,' Ulf Ekelund, ${ }^{2,3}$ Laila A Hopstock, ${ }^{4}$ Nils Abel Aars, ${ }^{4}$ \\ Marius Steiro Fimland, ${ }^{5,6}$ Bjarne Koster Jacobsen, ${ }^{4,7}$ Ola Løvsletten, ${ }^{4}$ Tom Wilsgaard, ${ }^{4}$ \\ Bente Morseth ${ }^{1}$
}

\begin{abstract}
- Additional material is published online only. To view, please visit the journal online (http://dx.doi.org/10.1136/ oemed-2020-106874).
\end{abstract}

For numbered affiliations see end of article.

Correspondence to Edvard H Sagelv, School of Sport Sciences, Faculty of Health Sciences, UiT The Arctic University of Norway, Tromsø, Troms, Norway; edvard.h.sagelv@uit.no

Received 8 July 2020 Revised 11 November 2020 Accepted 16 November 2020 Published Online First 4 December 2020

\section{Linked}

- http://dx.doi.org/10.1136/ oemed-2020-107266

Check for updates

(c) Author(s) (or their employer(s)) 2021. No commercial re-use. See rights and permissions. Published by BMJ.

To cite: Sagelv EH

Ekelund U, Hopstock LA,

et al. Occup Environ Med

2021:78:203-210

\section{ABSTRACT}

Objective To examine whether occupational physical activity changes predict future body mass index (BMI) changes.

Methods This longitudinal cohort study included adult participants attending $\geq 3$ consecutive Troms $\varnothing$ Study surveys (examinations 1, 2 and 3) from 1974 to 2016 $(\mathrm{N}=11308)$. If a participant attended $>3$ surveys, the three most recent surveys were included. Occupational physical activity change (assessed by the Saltin-Grimby Physical Activity Level Scale) was computed from the first to the second examination, categorised into persistently inactive $(n=3692)$, persistently active $(n=5560)$, active to inactive $(n=741)$ and inactive to active $(n=1315)$. BMI change was calculated from the second to the third examination (height being fixed at the second examination) and regressed on preceding occupational physical activity changes using analysis of covariance adjusted for sex, birth year, smoking, education and BMI at examination 2.

Results Overall, BMI increased by $0.84 \mathrm{~kg} / \mathrm{m}^{2}(95 \% \mathrm{Cl}$ 0.82 to 0.89 ). Following adjustments as described previously, we observed no differences in BMI increase between the occupational physical activity change groups (Persistently Inactive: $0.81 \mathrm{~kg} / \mathrm{m}^{2}, 95 \% \mathrm{Cl} 0.75$ to 0.87 ; Persistently Active: $0.87 \mathrm{~kg} / \mathrm{m}^{2}, 95 \% \mathrm{Cl} 0.82$ to 0.92 ; Active to Inactive: $0.81 \mathrm{~kg} / \mathrm{m}^{2}, 95 \% \mathrm{Cl} 0.67$ to 0.94; Inactive to Active: $0.91 \mathrm{~kg} / \mathrm{m}^{2}, 95 \% \mathrm{Cl} 0.81$ to $1.01 ; \mathrm{p}=0.25)$.

Conclusion We observed no prospective association between occupational physical activity changes and subsequent BMI changes. Our findings do not support the hypothesis that occupational physical activity declines contributed to population BMI gains over the past decades. Public health initiatives aimed at weight gain prevention may have greater success if focusing on other aspects than occupational physical activity.

\section{INTRODUCTION}

Excessive adiposity and weight gain arise from an imbalance between energy intake and expenditure. ${ }^{1}$ Increased energy intake is likely the main driver for population weight gains, ${ }^{2}$ but declines in physical activity levels may also contribute. ${ }^{13}$ At the population level, it may be easier to prevent weight gain by increasing physical activity levels than changing food habits. ${ }^{1}$ Although the evidence

\section{Key messages}

What is already known about this subject?

- The inconclusive results from observational studies on occupational physical activity change and body mass index (BMI) gain may be due to methodological issues.

What are the new findings?

- Occupational physical activity declines were not prospectively associated with BMI gains in this large population-based sample.

How might this impact on policy or clinical practice in the foreseeable future?

- Public health initiatives aimed at weight gain prevention may have greater success if focusing on other aspects than occupational physical activity.

for a prospective association between physical activity and weight gain is limited by methodological challenges, ${ }^{4}$ higher levels of physical activity are reported to prevent weight gain at the population level. ${ }^{5}$

Energy expenditure contribution from occupational physical activity is considered higher than that from leisure-time physical activity. ${ }^{3}{ }^{6}$ Since leisure-time physical activity appears stable over the past decades and occupational physical activity has declined in western countries, ${ }^{37-10}$ lower levels of occupational physical activity, rather than leisuretime physical activity, may contribute to population gains in weight. ${ }^{3} 1112$

Studies assessing the association between occupational physical activity and body mass index (BMI) or weight show conflicting results. ${ }^{11-16}$ Some studies reported no association between baseline occupational physical activity and future BMI change ${ }^{1113-16}$; however, baseline physical activity does not take the reciprocal relationship of changing weight and physical activity into account (ie, physical activity level at baseline may change over time to follow-up, which may be related or unrelated to weight change). ${ }^{4}$ Other studies computed change scores for both occupational physical activity and BMI and reported conflicting results ${ }^{12}{ }^{17}$; however, without adjusting for previous physical activity or 
$\mathrm{BMI} /$ weight at baseline, this represents a cross-sectional analysis of change scores (ie, it is as likely that physical activity change leads to weight change as vice versa), and thus, the direction of the association is unexamined. ${ }^{4}$

To overcome these methodological challenges, the aim of this study was to assess whether changes in occupational physical activity predicted future changes in BMI over a 40 -year period in a large cohort of Norwegian adults examined at three time points with $\sim 6$ years of follow-up between each time point.

\section{METHODS}

\section{Design}

The Tromsø Study is an ongoing population-based cohort study in the municipality of Tromsø, Norway, which includes seven repeated surveys with high attendance (\%): 1974 (Tromsø 1) (83\%), 1979-1980 (Tromsø 2) (85\%), 1986-1987 (Tromsø 3) (81\%), 1994-1995 (Tromsø 4) (77\%), 2001 (Tromsø 5) (79\%), 2007-2008 (Tromsø 6) (66\%) and 2015-2016 (Tromsø 7) $(65 \%)$. The cohort includes invited participants from total birth cohorts and random samples of inhabitants in the Tromsø municipality. ${ }^{10} 18$ Tromsø 1 included only men, while Troms $\varnothing$ 2-7 included both sexes (details described elsewhere (Tromsø $1-6^{18}$ and Troms $\left.\varnothing 7^{10}\right)$. In this study, we included participants attending at least three consecutive surveys (hereafter examinations 1-3). We computed change in physical activity from examination 1 to 2 followed by change in BMI and weight from examination 2 to 3 . Consequently, the follow-up period for physical activity change from examination 1 to 2 and BMI change from examination 2 to 3 were 6-7 years (mean: 6.5 years) for all included participants. Inclusion criteria were information on (1) physical activity at examination 1 and 2, and height and weight at examination 2 and 3; (2) educational level and smoking habits at examination 2; and (3) not pregnant at examination 2 and/or 3. If participants attended more than three consecutive surveys, data from the three most recent surveys were included in the main analyses (overall cohort), while one participant could be included in multiple period-specific samples (Tromsø 1-3: 1974-1987, Tromsø 2-4: 1979-1995, Tromsø 3-5: 1986-2001, Tromsø 4-6: 1994-2008 and Tromsø 5-7: 2001-2016). The layout for the analyses is illustrated in figure 1 .

\section{Participants}

A flowchart illustrates the selection of participants for our samples (online supplemental figure 1). In short, the overall cohort comprised 11308 participants with their three most recent attendances. The period-specific sample sizes were as follows: Tromsø 1-3 (1974-1987): n=3570, Tromsø 2-4 (19791995): $\mathrm{n}=9679$, Tromsø 3-5 (1986-2001): $\mathrm{n}=3827$, Tromsø

Examination 1
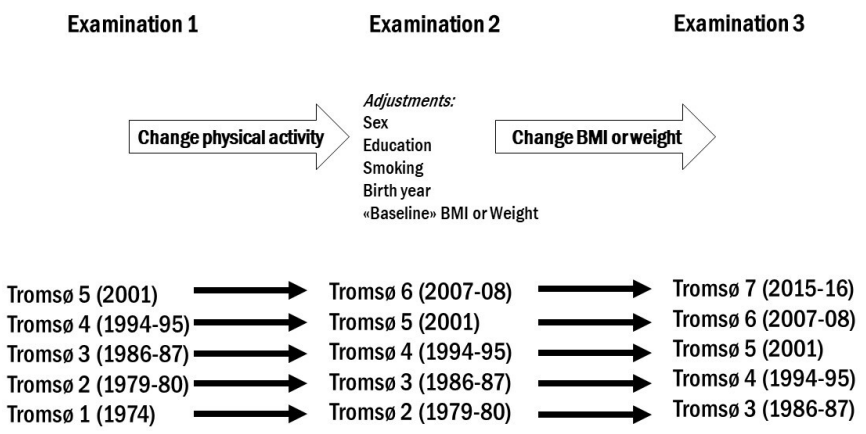

Figure 1 Layout for the analyses assessing the association between physical activity changes and future BMI change. BMI, body mass index.
4-6 (1994-2008): $\mathrm{n}=2212$ and Tromsø 5-7 (2001-2016): $\mathrm{n}=1146)$. Each individual was eligible for inclusion in multiple period-specific samples. Some participants were excluded due to missing confounders: Tromsø 1-3 (1974-1987): $\mathrm{n}=512$, Tromsø 2-4 (1979-1995): $\mathrm{n}=595$, Tromsø 3-5 (1986-2001): $\mathrm{n}=15$, Tromsø 4-6 (1994-2008): $\mathrm{n}=39$ and Tromsø 5-7 (20012016): $n=20$ (online supplemental figure 1).

The descriptive characteristics at examination 2 for the overall cohort and period-specific samples are presented in table 1. Tromsø 1 (1974) included only men; thus, the Troms $\varnothing$ 1-3 (1974-1987) sample included only men. All other cohorts are well balanced on sex distribution. Across period-specific samples, age distribution increases, current smokers decrease and educational-level increase (table 1).

\section{Patient and public involvement}

There was no public involvement in the design or implementation of this study. The Tromsø 7 advisory board included patient (University Hospital of North Norway) and public (Norwegian Health Association, Tromsø municipality) representatives, and some participants were invited as ambassadors during data collection where they actively contributed to participant recruitment.

\section{Physical activity}

Physical activity was measured using the Saltin-Grimby Physical Activity Level Scale (SGPALS) questionnaire ${ }^{1920}$ for occupational and leisure-time physical activity (leisure time during the last 12 months) (four hierarchical levels), slightly modified compared with the original SGPALS from $1968^{19}$ (differences described in online supplemental file 1; the SGPALS layout is presented in online supplemental table 1). For the occupational SGPALS, those reporting rank 1, predominantly sedentary work, were considered inactive; those reporting rank 2, sitting or standing work with some walking; rank 3, walking and some handling of material; or rank 4, heavy manual work, were considered active (online supplemental table 1). Similar inactive/active categorisation was used for the leisure time SGPALS (online supplemental table 1). The occupational SGPALS has shown acceptable reliability ${ }^{21}$ and an ability to rank participants compared with accelerometry. ${ }^{22}$

Change in occupational and leisure time SGPALS was computed as (1) persistently inactive (reporting rank 1 at examinations 1 and 2), (2) persistently active (rank $\geq 2$ at examinations 1 and 2), (3) active to inactive (rank $\geq 2$ at examination 1 and rank 1 at examination 2) and (4) inactive to active (rank 1 at examination 1 and rank $\geq 2$ at examination 2).

The occupational time SGPALS was used in all surveys of the Tromsø Study, while the leisure time SGPALS was used in all except Tromsø 4 (1994-1995). In Tromsø 5 (2001), the leisure time SGPALS was answered by those under 70 years.

\section{BMI and weight}

Weight and height were measured in light clothing and expressed as kilogram $(\mathrm{kg})$ and metre $(\mathrm{m})$. BMI at examination 2 was calculated as weight divided by the square height $\left(\mathrm{kg} / \mathrm{m}^{2}\right)$. To eliminate the effect of possible height loss between examination 2 and 3, change in BMI at examination 3 was calculated as weight at examination 3 divided by the square height at examination 2 . BMI change is our primary outcome, while weight change results are secondary outcomes (online supplemental tables 2 and 3 and 5-9).

\section{Confounders and effect modifiers}

Our selected confounders were sex, birth year, smoking, education and baseline BMI/weight (at examination 2). Effect 
Table 1 Descriptive characteristics of the overall cohort and period-specific samples. The Tromsø Study 1974-2016

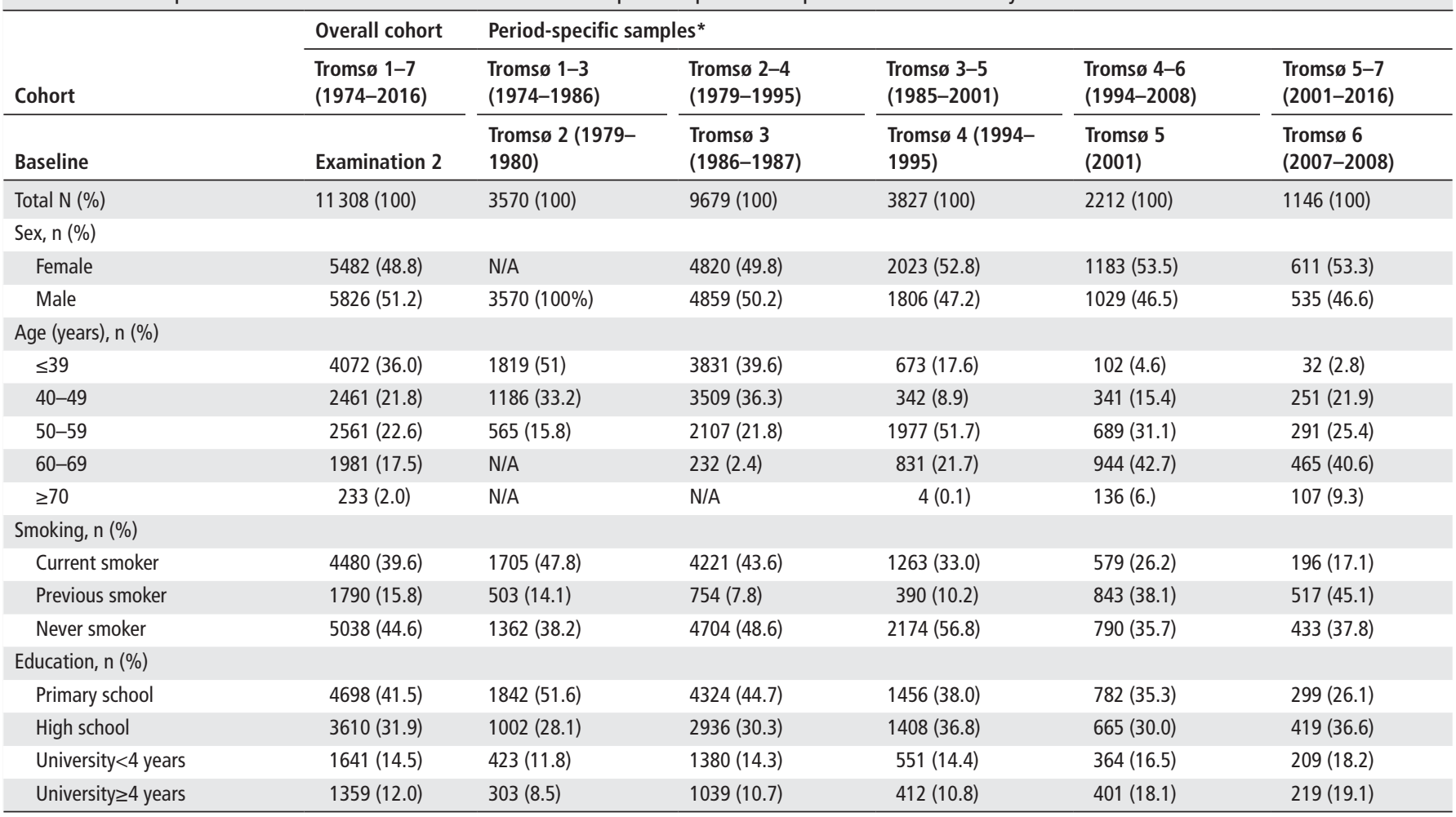

*Period-specific samples include all participants meeting our inclusion criteria for that period (ie, these samples do not add up to the overall cohort (Tromsø 1-7), which includes participants with their three most recent attendances).

modifiers included the abovementioned confounders, in addition to leisure-time physical activity change. Smoking (from questionnaire) was categorised into (1) current smoker, (2) previous smoker and (3) never smoker. Years of education (from questionnaire) were reported in Tromsø 2 (1979-1980), Tromsø 3 (1986-1987) and Tromsø 5 (2001), which we categorised into (1) primary school (<10 years), (2) high school (10-12 years), (3) university $<4$ years (13-15 years) and (4) university $\geq 4$ years ( $\geq 16$ years). A five-group alternative for education was reported in Tromsø 4 (1994-1995) and Tromsø 6 (2007-2008), including the four aforementioned groups and a fifth named 'technical school 2 years senior high' (eg, craftsman, plumber, electrician and carpenter), which we categorised as high school. All confounders included in the models were retrieved from examination 2.

\section{Statistical analyses}

We used paired t-tests to assess whether participants changed BMI and weight from examination 2 to 3 . We used analysis of covariance to assess whether physical activity changes from examination 1 to 2 predicted BMI or weight changes from examination 2 to 3 as overall and in strata of sex, birth year, smoking, education and leisure-time physical activity change, with adjustment for sex, birth year, smoking, education and BMI or weight at examination 2. Q-Q plots confirmed change in BMI and weight from examination 2 to 3 to not deviate from normal distribution. The Levene test of equality variance confirmed homogeneity of variance across occupational physical activity change groups (all $\mathrm{p}>0.07$ ). We assessed interaction effects between occupational physical activity change and potential effect modifiers (sex, birth year, smoking, education and leisure-time physical activity change from examination 1 to 2 ) in the overall cohort. For sensitivity analyses, we computed occupational physical activity change into six groups: (1) Persistently Inactive, (2) Persistently Active, (3) active but decreasing (rank 4 or $3 \rightarrow 3$ or 2), (4) active and increasing (rank 2 or $3 \rightarrow 3$ or 4), (5) Active to Inactive and (6) Inactive to Active. Data are shown as mean and 95\% CIs unless otherwise stated. We used the Statistical Package for Social Sciences V.26 for all statistical analyses.

\section{RESULTS}

The participants in the overall cohort and period-specific samples increased their BMI from examination 2 to 3 (all $\mathrm{p}<0.01$ ) (table 2). Weight change results are shown in online supplemental table 2).

\section{Change in BMI by change in occupational physical activity}

Changes in BMI by occupational physical activity change, overall and by strata of sex, birth year, smoking, education and leisure-time physical activity changes are presented in table 3. We observed no differences in BMI change from examination 2 to 3 by occupational physical activity changes from examination 1 to 2 (Persistently Inactive: $0.81 \mathrm{~kg} / \mathrm{m}^{2}, 95 \% \mathrm{CI} 0.75$ to 0.87 ; Persistently Active: $0.87 \mathrm{~kg} / \mathrm{m}^{2}, 95 \% \mathrm{CI} 0.82$ to 0.92 ; Active to Inactive: $0.81 \mathrm{~kg} / \mathrm{m}^{2}, 95 \% \mathrm{CI} 0.67$ to 0.94 ; Inactive to Active: $0.91 \mathrm{~kg} / \mathrm{m}^{2}, 95 \%$ CI 0.81 to $1.01 ; \mathrm{p}=0.25$ ), which was consistent in stratified analyses (all $\mathrm{p} \geq 0.054$ ) (table 3).

We found no interaction effects of potential effect modifiers for the association between occupational physical activity changes and BMI changes (sex: $p=0.87$, smoking status: $\mathrm{p}=0.64$, education: $\mathrm{p}=0.25$ and leisure-time physical activity changes: $p=0.24)$, except by birth year $(p=0.01)$.

Overall and stratified weight change results for the overall cohort are found in online supplemental table 3; we found no differences in weight change from examination 2 to 3 by 
Table 2 BMI at examinations 2 and 3 and BMI change in the overall cohort and period-specific samples. The Tromsø Study $1974-2016$.

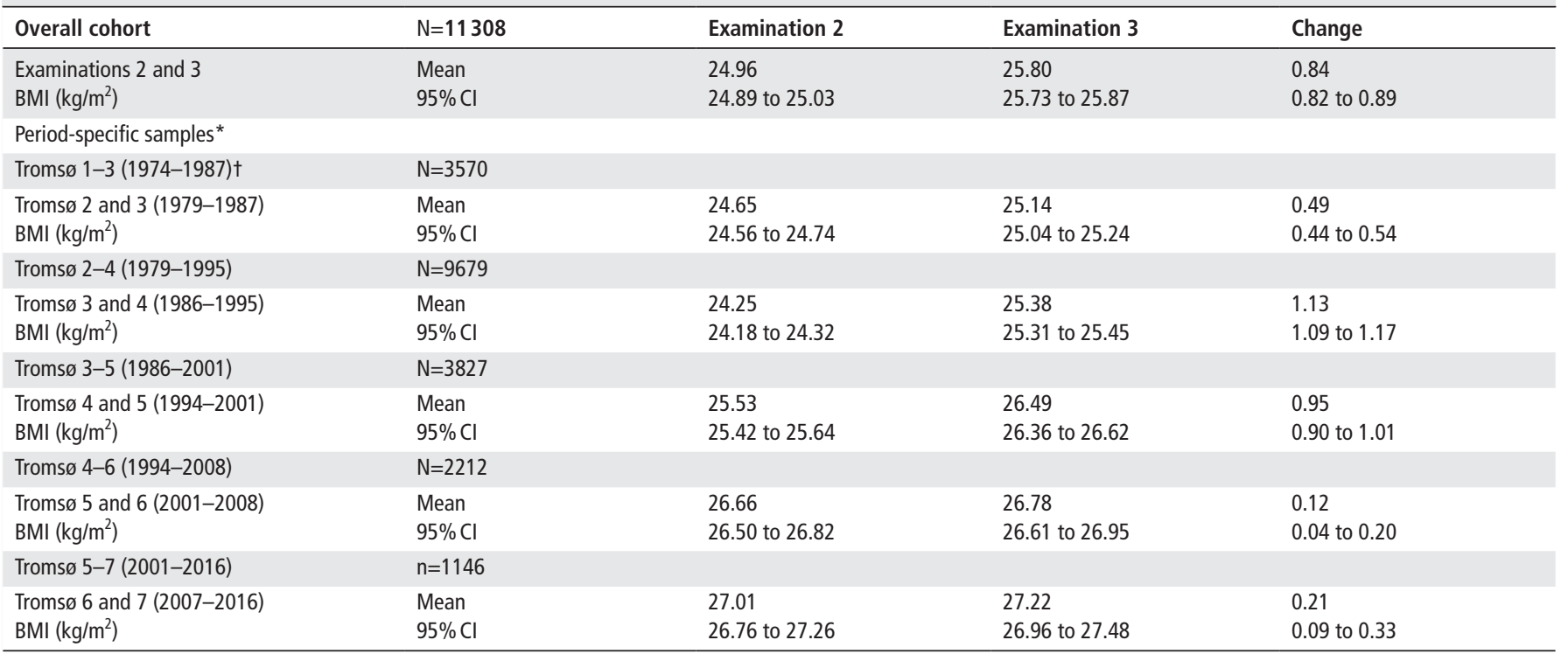

Data are shown as unadjusted mean and $95 \% \mathrm{Cl}$. Examination 2 refers to the second survey of the three attended surveys; examination 3 refers to the third survey of the three attended surveys.

*Period-specific samples include all participants meeting our inclusion criteria for that period (ie, these samples do not add up to the overall cohort (Tromsø 1-7), which includes participants with their three most recent attendances).

†Tromsø 1 included only men.

BMI, body mass index.

occupational physical activity change from examination 1 to 2 (all $\mathrm{p} \geq 0.049$ ).

In the sensitivity analyses, where we computed occupational physical activity change into six groups (1) Persistently Inactive, (2) Persistently Active, (3) Active but Decreasing (rank 4 or 3 to 3 or 2), (4) Active and Increasing (rank 2 or 3 to 3 or 4), (5) Active to Inactive and (6) Inactive to Active, the results generally remained unchanged (overall analysis: $p=0.15$ ); however, some differences were observed in some strata analyses (birth year, born $\leq 1929$ : $p=0.03$; education, high school: $p=0.04$, university $\geq 4$ years: $p=0.049$; and leisure-time physical activity changes; PA: $p=0.003$ ) (online supplemental table 4). We found no interaction in the association between occupational physical activity change and BMI change (sex: $p=0.21$, smoking: $\mathrm{p}=0.59$, education: $\mathrm{p}=0.88$, leisure-time physical activity change: $p=0.12$, except by birth year: $p=0.04$ ).

We observed no differences in BMI change by occupational physical activity change in any period-specific sample (table 4): (1) there were no differences in BMI change from Tromsø 2 (1979-1980) to Tromsø 3 (1986-1987) between the physical activity change groups from Tromsø 1 (1974) to Tromsø 2 (1979-1980) $(\mathrm{p}=0.68)$, (2) BMI change from Tromsø 3 (1986-1987) to Tromsø 4 (1994-1995) between the physical activity change groups from Tromsø 2 (1979-1980) to Tromsø 3 (1986-1987) $(\mathrm{p}=0.50)$, (3) BMI change from Tromsø 4 (1994$1995)$ to Tromsø 5 (2001) between the physical activity change groups from Tromsø 3 (1986-1987) to Tromsø 4 (1994-1995) $(\mathrm{p}=0.90),(4)$ BMI change from Tromsø 5 (2001) to Tromsø 6 (2007-2008) between the physical activity change groups from Tromsø 4 (1994-1995) to Tromsø 5 (2001) ( $\mathrm{p}=0.98)$, (5) BMI change from Tromsø 6 (2007-2008) to Tromsø 7 (2015-2016) between the physical activity change groups from Tromsø 5 (2001) to Tromsø 6 (2007-2008) $(\mathrm{p}=20)$. Stratified analyses for the period-specific samples are presented in online supplemental tables 5-9). We observed no differences in BMI or weight change by occupational physical activity change in any strata analysis (all $\mathrm{p} \geq 0.13$; except Tromsø 2-4 (1979-1995) sample, $\geq 4$ years university education: $\mathrm{p} \leq 0.04$; online supplemental table 8 ).

\section{DISCUSSION}

In this large Norwegian population-based prospective study over four decades, we found no association between occupational physical activity changes and future BMI and weight changes.

Most previous longitudinal studies examined the association between baseline occupational physical activity and future BMI change, ${ }^{13-16}$ which do not account for the reciprocal temporal changes in physical activity and BMI. ${ }^{4}$ Two studies assessed changes in both occupational physical activity and BMI where one found lower occupational physical activity to be associated with weight gain, ${ }^{12}$ while one found no association. ${ }^{17}$ Without adjustment for previous physical activity levels, the direction of association and thus indication of causality, remains uncertain. ${ }^{4}$ Our study corroborates the findings of a recent study by Dobson et $a l^{23}$ which regressed trajectories of self-reported BMI (ie, weight and height) on physical work exertion trajectories over nine time points in Canadian adults and showed no association between physical work exertion change and BMI trajectories, except for higher odds of being in a very obese trajectory (from 36 to $40 \mathrm{~kg} / \mathrm{m}^{2}$ at follow-up) compared to a reference normal weight trajectory (22 to $24 \mathrm{~kg} / \mathrm{m}^{2}$ ) with no higher odds of being in other BMI trajectories among those who decreased their physical work exertion compared with those who sustained low physical work exertion. ${ }^{23}$ Our study expands the work by Dobson et al ${ }^{23}$ by using measured weight and height on both examinations and non-dichotomized BMI change as the outcome. Consequently, with higher accuracy in the outcome, ${ }^{24}$ the observed magnitudes in the association between occupational physical activity change and BMI change can be interpreted with higher confidence. ${ }^{4}$

As we did not adjust for energy intake due to unavailable data, our results may be influenced by residual confounding. Nevertheless, a previous study estimated that increasing physical activity 
Table 3 BMI change by occupational physical activity change for the overall cohort and in strata of sex, birth year, smoking, education and leisuretime physical activity change. The Tromsø Study 1974-2016.

\begin{tabular}{|c|c|c|c|c|c|c|}
\hline \multirow{2}{*}{$\begin{array}{l}\text { Tromsø 1-7 } \\
(1974-2016)\end{array}$} & \multicolumn{5}{|c|}{ Change occupational physical activity examinations 1 and 2} & \multirow[b]{2}{*}{$P_{\text {equality }}$} \\
\hline & Total & Persistently Inactive & Persistently Active & Active to Inactive & Inactive to Active & \\
\hline & \multicolumn{5}{|c|}{ BMI change examinations 2 and 3} & \\
\hline Total (N) & 11308 & 3692 & 5560 & 741 & 1315 & \\
\hline BMI $\left(\mathrm{kg} / \mathrm{m}^{2}\right)$ & $\begin{array}{l}\text { Mean } \\
95 \% \mathrm{Cl}\end{array}$ & $\begin{array}{l}0.81 \\
0.75 \text { to } 0.87\end{array}$ & $\begin{array}{l}0.87 \\
0.82 \text { to } 0.92\end{array}$ & $\begin{array}{l}0.81 \\
0.67 \text { to } 0.94\end{array}$ & $\begin{array}{l}0.91 \\
0.81 \text { to } 1.01\end{array}$ & 0.25 \\
\hline \multicolumn{7}{|l|}{ Sex } \\
\hline Women (n) & 5482 & 1638 & 2925 & 319 & 600 & \\
\hline BMI $\left(\mathrm{kg} / \mathrm{m}^{2}\right)$ & $\begin{array}{l}\text { Mean } \\
95 \% \mathrm{Cl}\end{array}$ & $\begin{array}{l}1.06 \\
0.96 \text { to } 1.17\end{array}$ & $\begin{array}{l}1.09 \\
1.02 \text { to } 1.17\end{array}$ & $\begin{array}{l}1.10 \\
0.87 \text { to } 1.33\end{array}$ & $\begin{array}{l}1.18 \\
1.01 \text { to } 1.34\end{array}$ & 0.74 \\
\hline Men (n) & 5826 & 2054 & 2635 & 422 & 715 & \\
\hline $\mathrm{BMI}\left(\mathrm{kg} / \mathrm{m}^{2}\right)$ & $\begin{array}{l}\text { Mean } \\
95 \% \mathrm{Cl}\end{array}$ & $\begin{array}{l}0.56 \\
0.49 \text { to } 0.63\end{array}$ & $\begin{array}{l}0.67 \\
0.61 \text { to } 0.74\end{array}$ & $\begin{array}{l}0.55 \\
0.39 \text { to } 0.71\end{array}$ & $\begin{array}{l}0.66 \\
0.54 \text { to } 0.78\end{array}$ & 0.11 \\
\hline \multicolumn{7}{|l|}{ Birth year } \\
\hline$\leq 1929(n)$ & 748 & 239 & 350 & 60 & 99 & \\
\hline BMI $\left(\mathrm{kg} / \mathrm{m}^{2}\right)$ & $\begin{array}{l}\text { Mean } \\
95 \% \mathrm{Cl}\end{array}$ & $\begin{array}{l}0.09 \\
0.31 \text { to } 0.14\end{array}$ & $\begin{array}{l}0.15 \\
-0.03 \text { to } 0.33\end{array}$ & $\begin{array}{l}0.20 \\
-0.22 \text { to } 0.62\end{array}$ & $\begin{array}{l}0.31 \\
0.64 \text { to } 0.01\end{array}$ & 0.054 \\
\hline $1930-1939(n)$ & 2974 & 856 & 1580 & 189 & 349 & \\
\hline BMI $\left(\mathrm{kg} / \mathrm{m}^{2}\right)$ & $\begin{array}{l}\text { Mean } \\
95 \% \mathrm{Cl}\end{array}$ & $\begin{array}{l}0.43 \\
0.30 \text { to } 0.57\end{array}$ & $\begin{array}{l}0.53 \\
0.43 \text { to } 0.62\end{array}$ & $\begin{array}{l}0.55 \\
0.28 \text { to } 0.82\end{array}$ & $\begin{array}{l}0.36 \\
0.16 \text { to } 0.56\end{array}$ & 0.39 \\
\hline 1940-1949 (n) & 4192 & 1483 & 2020 & 260 & 429 & \\
\hline BMI $\left(\mathrm{kg} / \mathrm{m}^{2}\right)$ & $\begin{array}{l}\text { Mean } \\
95 \% \mathrm{Cl}\end{array}$ & $\begin{array}{l}0.85 \\
0.75 \text { to } 0.95\end{array}$ & $\begin{array}{l}0.92 \\
0.84 \text { to } 1.00\end{array}$ & $\begin{array}{l}0.73 \\
0.50 \text { to } 0.96\end{array}$ & $\begin{array}{l}1.06 \\
0.88 \text { to } 1.24\end{array}$ & 0.10 \\
\hline 1950-1959 (n) & 3947 & 932 & 1430 & 205 & 380 & \\
\hline BMI $\left(\mathrm{kg} / \mathrm{m}^{2}\right)$ & $\begin{array}{l}\text { Mean } \\
95 \% \mathrm{Cl}\end{array}$ & $\begin{array}{l}1.34 \\
1.22 \text { to } 1.45\end{array}$ & $\begin{array}{l}1.28 \\
1.19 \text { to } 1.37\end{array}$ & $\begin{array}{l}1.28 \\
1.04 \text { to } 1.52\end{array}$ & $\begin{array}{l}1.52 \\
1.34 \text { to } 1.70\end{array}$ & 0.12 \\
\hline$\geq 1960$ (n) & 447 & 182 & 180 & 27 & 58 & \\
\hline BMI $\left(\mathrm{kg} / \mathrm{m}^{2}\right)$ & $\begin{array}{l}\text { Mean } \\
95 \% \mathrm{Cl}\end{array}$ & $\begin{array}{l}1.04 \\
0.69 \text { to } 1.39\end{array}$ & $\begin{array}{l}1.11 \\
0.75 \text { to } 1.46\end{array}$ & $\begin{array}{l}1.13 \\
0.24 \text { to } 2.02\end{array}$ & $\begin{array}{l}1.34 \\
0.72 \text { to } 1.95\end{array}$ & 0.88 \\
\hline \multicolumn{7}{|l|}{ Smoking } \\
\hline Current smoker (n) & 4480 & 1250 & 2343 & 306 & 581 & \\
\hline BMI $\left(\mathrm{kg} / \mathrm{m}^{2}\right)$ & $\begin{array}{l}\text { Mean } \\
95 \% \mathrm{Cl}\end{array}$ & $\begin{array}{l}0.96 \\
0.85 \text { to } 1.07\end{array}$ & $\begin{array}{l}1.00 \\
0.92 \text { to } 1.08\end{array}$ & $\begin{array}{l}0.82 \\
0.60 \text { to } 1.03\end{array}$ & $\begin{array}{l}1.02 \\
0.86 \text { to } 1.17\end{array}$ & 0.44 \\
\hline Previous smoker (n) & 1790 & 703 & 782 & 126 & 179 & \\
\hline BMI $\left(\mathrm{kg} / \mathrm{m}^{2}\right)$ & $\begin{array}{l}\text { Mean } \\
95 \% \mathrm{Cl}\end{array}$ & $\begin{array}{l}0.34 \\
0.19 \text { to } 0.48\end{array}$ & $\begin{array}{l}0.42 \\
0.28 \text { to } 0.55\end{array}$ & $\begin{array}{l}0.52 \\
0.19 \text { to } 0.85\end{array}$ & $\begin{array}{l}0.43 \\
0.16 \text { to } 0.71\end{array}$ & 0.71 \\
\hline Never smoker (n) & 5038 & 1739 & 2435 & 309 & 555 & \\
\hline $\mathrm{BMI}\left(\mathrm{kg} / \mathrm{m}^{2}\right)$ & $\begin{array}{l}\text { Mean } \\
95 \% \mathrm{Cl}\end{array}$ & $\begin{array}{l}0.87 \\
0.78 \text { to } 0.95\end{array}$ & $\begin{array}{l}0.91 \\
0.83 \text { to } 0.98\end{array}$ & $\begin{array}{l}0.91 \\
0.71 \text { to } 1.10\end{array}$ & $\begin{array}{l}0.95 \\
0.81 \text { to } 1.10\end{array}$ & 0.79 \\
\hline \multicolumn{7}{|l|}{ Education } \\
\hline Primary school (n) & 4698 & 878 & 3010 & 265 & 545 & \\
\hline BMI $\left(\mathrm{kg} / \mathrm{m}^{2}\right)$ & $\begin{array}{l}\text { Mean } \\
95 \% \mathrm{Cl}\end{array}$ & $\begin{array}{l}0.75 \\
0.62 \text { to } 0.88\end{array}$ & $\begin{array}{l}0.83 \\
0.76 \text { to } 0.90\end{array}$ & $\begin{array}{l}0.68 \\
0.45 \text { to } 0.92\end{array}$ & $\begin{array}{l}0.79 \\
0.63 \text { to } 0.95\end{array}$ & 0.52 \\
\hline High school (n) & 3610 & 1361 & 1566 & 271 & 412 & \\
\hline $\mathrm{BMI}\left(\mathrm{kg} / \mathrm{m}^{2}\right)$ & $\begin{array}{l}\text { Mean } \\
95 \% \mathrm{Cl}\end{array}$ & $\begin{array}{l}0.87 \\
0.77 \text { to } 0.97\end{array}$ & $\begin{array}{l}0.95 \\
0.86 \text { to } 1.04\end{array}$ & $\begin{array}{l}0.82 \\
0.60 \text { to } 1.03\end{array}$ & $\begin{array}{l}1.11 \\
0.93 \text { to } 1.29\end{array}$ & 0.09 \\
\hline University<4 years $(\mathrm{n})$ & 1641 & 787 & 539 & 117 & 198 & \\
\hline $\mathrm{BMI}\left(\mathrm{kg} / \mathrm{m}^{2}\right)$ & $\begin{array}{l}\text { Mean } \\
95 \% \mathrm{Cl}\end{array}$ & $\begin{array}{l}0.85 \\
0.72 \text { to } 0.98\end{array}$ & $\begin{array}{l}0.90 \\
0.75 \text { to } 1.06\end{array}$ & $\begin{array}{l}0.88 \\
0.55 \text { to } 1.21\end{array}$ & $\begin{array}{l}0.97 \\
0.71 \text { to } 1.22\end{array}$ & 0.85 \\
\hline University>4 years $(n)$ & 1359 & 666 & 445 & 88 & 160 & \\
\hline BMI $\left(k g / m^{2}\right)$ & $\begin{array}{l}\text { Mean } \\
95 \% \mathrm{Cl}\end{array}$ & $\begin{array}{l}0.72 \\
0.59 \text { to } 0.85\end{array}$ & $\begin{array}{l}0.80 \\
0.64 \text { to } 0.96\end{array}$ & $\begin{array}{l}1.16 \\
0.81 \text { to } 1.50\end{array}$ & $\begin{array}{l}0.75 \\
0.49 \text { to } 1.01\end{array}$ & 0.14 \\
\hline \multicolumn{7}{|c|}{ Leisure time physical activity change examinations 1 and $2^{*}$} \\
\hline Persistently Inactive (n) & 813 & 332 & 317 & 63 & 101 & \\
\hline BMI $\left(k g / m^{2}\right)$ & $\begin{array}{l}\text { Mean } \\
95 \% \mathrm{Cl}\end{array}$ & $\begin{array}{l}0.81 \\
0.60 \text { to } 1.03\end{array}$ & $\begin{array}{l}0.98 \\
0.76 \text { to } 1.20\end{array}$ & $\begin{array}{l}1.25 \\
0.76 \text { to } 1.73\end{array}$ & $\begin{array}{l}0.94 \\
0.55 \text { to } 1.33\end{array}$ & 0.42 \\
\hline Persistently Active (n) & 5368 & 1599 & 2798 & 328 & 643 & \\
\hline BMI $\left(\mathrm{kg} / \mathrm{m}^{2}\right)$ & $\begin{array}{l}\text { Mean } \\
95 \% \mathrm{Cl}\end{array}$ & $\begin{array}{l}1.00 \\
0.91 \text { to } 1.08\end{array}$ & $\begin{array}{l}1.02 \\
0.95 \text { to } 1.08\end{array}$ & $\begin{array}{l}0.82 \\
0.63 \text { to } 1.02\end{array}$ & $\begin{array}{l}1.13 \\
1.00 \text { to } 1.27\end{array}$ & 0.08 \\
\hline
\end{tabular}


Table 3 continued

\begin{tabular}{|c|c|c|c|c|c|c|}
\hline Tromsø 1-7 & Change & al physical activity ex & aminations 1 and 2 & & & \\
\hline (1974-2016) & Total & Persistently Inactive & Persistently Active & Active to Inactive & Inactive to Active & $P_{\text {equality }}$ \\
\hline Active to Inactive (n) & 974 & 291 & 469 & 71 & 143 & \\
\hline BMI $\left(\mathrm{kg} / \mathrm{m}^{2}\right)$ & $\begin{array}{l}\text { Mean } \\
95 \% \mathrm{Cl}\end{array}$ & $\begin{array}{l}0.82 \\
0.60 \text { to } 1.04\end{array}$ & $\begin{array}{l}1.03 \\
0.86 \text { to } 1.21\end{array}$ & $\begin{array}{l}1.24 \\
0.80 \text { to } 1.68\end{array}$ & $\begin{array}{l}1.11 \\
0.80 \text { to } 1.42\end{array}$ & 0.23 \\
\hline Inactive to Active (n) & 999 & 348 & 451 & 66 & 134 & \\
\hline BMI $\left(\mathrm{kg} / \mathrm{m}^{2}\right)$ & $\begin{array}{l}\text { Mean } \\
95 \% \mathrm{Cl}\end{array}$ & $\begin{array}{l}0.90 \\
0.69 \text { to } 1.11\end{array}$ & $\begin{array}{l}1.09 \\
0.91 \text { to } 1.28\end{array}$ & $\begin{array}{l}0.89 \\
0.42 \text { to } 1.37\end{array}$ & $\begin{array}{l}0.77 \\
0.43 \text { to } 1.10\end{array}$ & 0.31 \\
\hline
\end{tabular}

Data are adjusted for sex, birth year, smoking, education and BMI at examination 2, and are shown as adjusted mean and $95 \% \mathrm{Cl}$. Examination 1 refers to the first survey of the three attended surveys; examination 2 refers to the second survey of the three attended surveys; examination 3 refers to the third survey of the three attended surveys. $P_{\text {equality }}$ is the main difference between groups.

*The leisure-time Saltin-Grimby Physcial Activity Scale was not included in Tromsø 4 (1994-1995).

$\mathrm{BMI}$, body mass index.

energy expenditures of about $100 \mathrm{kcal} /$ day would be sufficient for weight gain prevention at the population level, ${ }^{25}$ indicating that equivalent decreases would result in weight gain. This is similar to the estimated lower energy expenditure deriving from declines in occupational physical activity. ${ }^{3}$ As leisure time physical activity influences energy expenditure, one could hypothesise that occupational physical activity decline is only hazardous for those being physically inactive in leisure time. However, we observed no effect modification by leisure time physical activity changes.

It has been suggested that achieving energy balance and weight stability is easier at higher energy turnover. ${ }^{1}$ For example, energy intake increased by $500 \mathrm{kcal} /$ day from the $1970 \mathrm{~s}$ to $2000 \mathrm{~s}$ in the USA, and 110-150 min of walking per day is needed to compensate for this increase. ${ }^{26}$ Consequently, as $150 \mathrm{~min}$ of walking per day is up to seven times higher than the current minimum recommendations for physical activity $(150 \mathrm{~min} / \mathrm{week}),{ }^{27}$ and considering that one out of three adults in Western high-income countries fail to meet the recommendations, ${ }^{28}$ it is unlikely that the physical activity volume performed by the general population is sufficiently high to prevent weight gain. ${ }^{29}$

As occupational physical activity energy expenditure is dependent on activity duration, the effect of occupational physical activity on weight gain prevention may be influenced by whether individuals work full or part time. Thus, as we did not adjust for full-time and part-time work due to unavailable data, this may also have introduced residual confounding. However, these energy expenditure differences may in reality be small. For example, heavy manual labour workers are estimated to work at $\sim 30 \%$ to $35 \%$ of maximal oxygen uptake over an 8 hours work day, ${ }^{30}$ which can be a sufficient volume to compensate the $500 \mathrm{kcal} / \mathrm{day}$ energy intake increase. ${ }^{26}$ However, few individuals in the Tromsø Study report heavy manual labour $\left(\sim 8 \%\right.$ in $1979-1980, \sim 2 \%$ in $\left.2015-2016^{10}\right)$. In contrast, most

Table 4 BMl changes by occupational physical activity change in period-specific samples. The Tromsø Study 1974-2016.

\begin{tabular}{|c|c|c|c|c|c|c|}
\hline \multirow[b]{2}{*}{ Period-specific samples* } & \multicolumn{5}{|c|}{ Change occupational physical activity examinations 1 and 2} & \multirow[b]{2}{*}{$\mathbf{P}_{\text {equality }}$} \\
\hline & Total & Persistently inactive & Persistently active & Active to inactive & Inactive to active & \\
\hline Tromsø 1-3 (1974-1987)\# & n & & & & & \\
\hline Tromsø 2-3 (1979-1987) & 3570 & 1033 & 1805 & 366 & 366 & \\
\hline BMI $\left(\mathrm{kg} / \mathrm{m}^{2}\right)$ & $\begin{array}{l}\text { Mean } \\
95 \% \mathrm{Cl}\end{array}$ & $\begin{array}{l}0.48 \\
0.39 \text { to } 0.57\end{array}$ & $\begin{array}{l}0.48 \\
0.41 \text { to } 0.54\end{array}$ & $\begin{array}{l}0.49 \\
0.35 \text { to } 0.64\end{array}$ & $\begin{array}{l}0.57 \\
0.43 \text { to } 0.71\end{array}$ & 0.68 \\
\hline Tromsø 2-4 (1979-1995) & $\mathrm{n}$ & & & & & \\
\hline Tromsø 3 and 4 (1986-1995) & 9679 & 2512 & 5179 & 665 & 1323 & \\
\hline $\mathrm{BMI}\left(\mathrm{kg} / \mathrm{m}^{2}\right)$ & $\begin{array}{l}\text { Mean } \\
95 \% \mathrm{Cl}\end{array}$ & $\begin{array}{l}1.12 \\
1.05 \text { to } 1.19\end{array}$ & $\begin{array}{l}1.15 \\
1.10 \text { to } 1.20\end{array}$ & $\begin{array}{l}1.12 \\
0.99 \text { to } 1.26\end{array}$ & $\begin{array}{l}1.07 \\
0.98 \text { to } 1.17\end{array}$ & 0.50 \\
\hline Tromsø 3-5 (1986-2002) & $\mathrm{n}$ & & & & & \\
\hline Tromsø 4 and 5 (1994-2001) & 3827 & 1315 & 1915 & 223 & 374 & \\
\hline BMI $\left(\mathrm{kg} / \mathrm{m}^{2}\right)$ & $\begin{array}{l}\text { Mean } \\
95 \% \mathrm{Cl}\end{array}$ & $\begin{array}{l}0.96 \\
0.86 \text { to } 1.05\end{array}$ & $\begin{array}{l}0.96 \\
0.87 \text { to } 1.04\end{array}$ & $\begin{array}{l}1.02 \\
0.79 \text { to } 1.25\end{array}$ & $\begin{array}{l}0.91 \\
0.73 \text { to } 1.09\end{array}$ & 0.90 \\
\hline Tromsø 4-6 (1994-2008) & $\mathrm{n}$ & & & & & \\
\hline Tromsø 5 and 6 (2001-2008) & 2212 & 884 & 985 & 166 & 177 & \\
\hline BMI $\left(\mathrm{kg} / \mathrm{m}^{2}\right)$ & $\begin{array}{l}\text { Mean } \\
95 \% \mathrm{Cl}\end{array}$ & $\begin{array}{l}0.12 \\
-0.004 \text { to } 0.24\end{array}$ & $\begin{array}{l}0.12 \\
0.01 \text { to } 0.24\end{array}$ & $\begin{array}{l}0.15 \\
-0.13 \text { to } 0.43\end{array}$ & $\begin{array}{l}0.07 \\
-0.20 \text { to } 0.35\end{array}$ & 0.98 \\
\hline Tromsø 5-7 (2001-2016) & $\mathrm{n}$ & & & & & \\
\hline Tromsø 6 and 7 (2007-2016) & 1146 & 481 & 501 & 60 & 104 & \\
\hline BMI $\left(\mathrm{kg} / \mathrm{m}^{2}\right)$ & $\begin{array}{l}\text { Mean } \\
95 \% \mathrm{Cl}\end{array}$ & $\begin{array}{l}0.07 \\
-0.11 \text { to } 0.25\end{array}$ & $\begin{array}{l}0.35 \\
0.17 \text { to } 0.53\end{array}$ & $\begin{array}{l}0.14 \\
-0.36 \text { to } 0.64\end{array}$ & $\begin{array}{l}0.21 \\
-0.17 \text { to } 0.60\end{array}$ & 0.20 \\
\hline
\end{tabular}

Data are adjusted for sex, birth year, smoking, education and BMI at examination 2, and are shown as adjusted mean and $95 \% \mathrm{Cl}_{\text {. }} \mathrm{P}_{\text {equality }}$ is the main difference between groups. *Period-specific samples include all participants for that period (ie, these samples do not add up to the overall cohort (Tromsø 1-7), which includes participants with their three most recent attendances),

†Tromsø 1 included only men.

BMI, body mass index. 
occupational physical activities in the Tromsø Study changed from standing and walking to sitting, ${ }^{10}$ which is consistent with some cohorts. ${ }^{3} 1112$ The energy expenditure difference while sitting compared with standing is estimated to be $54 \mathrm{kcal}$ over 6 hours (ie, $72 \mathrm{kcal}$ over 8 hours), ${ }^{31}$ which is unlikely to have any apparent effect on weight gain.

Some study cohorts in Southern Europe include a substantially larger proportion of heavy manual labour workers (Portugal, $37 \%{ }^{32}$; Spain, Barcelona, $68 \%{ }^{17}$ ); however, this is not consistent (Madrid, Spain: 2\%, Italy: $8 \%{ }^{34}$ ). Consequently, the generalisability of our findings may be limited to Northern/Central European $^{8-10}$ and North American ${ }^{311}$ high-income countries. Studies examining weight gain prevention in heavy manual labour workers may be a future research target.

In our study, $741(7 \%)$ participants are categorised as 'Active to Inactive', while 1315 (12\%) participants were categorised as 'Inactive to Active' (table 3), indicating that more individuals increased their occupational physical activity level in our cohort. However, this is due to our crude categorisation of physical activity change; in our sensitivity analysis, 1315 (12\%) are categorised as active but decreasing (rank 4 or $3 \rightarrow$ rank 3 or 2) (online supplemental table 4), where these are categorised as 'Persistently Active' in our main analysis ( rank $\geq 2 \rightarrow$ rank $\geq 2$ ) (table 3). Thus, the consistent pattern of declining occupational physical activity levels as in previous studies ${ }^{3-10}$ is confirmed in our study.

Our results indicate that occupational physical activity declines play a minor, if any, role in the observed population gain in BMI and weight. Consequently, public health initiatives aimed at weight gain prevention may have greater success by focusing on other aspects than occupational physical activity, for example, intake of energy dense food. ${ }^{26}$

The association between physical activity and BMI gain may also be reversed and/or bidirectional. ${ }^{4}$ High body weight appears causally associated with lower levels of physical activity when examining these associations using a Mendelian randomisation approach. ${ }^{35}$ However, intuitively, leisure-time physical activity is self-regulated while occupational physical activity is less controllable by the individual. Whether individuals regulate their occupational physical activity level depending on their BMI gain is questionable.

\section{Strengths}

First, as population gains in BMI have gradually increased over decades, ${ }^{36}$ the long follow-up time ( $\sim 6$ years) between each examination allowed us to examine whether occupational physical activity has contributed to BMI gain in this cohort. ${ }^{4}$ Second, by computing change in physical activity followed by change in BMI (accounting for previous physical activity level), we are able to interpret the direction of the association with more certainty. ${ }^{4}$ Third, by merging our period-specific samples to an overall cohort, we had higher power to examine multiple potential effect modifiers (table 3). For example, one warranted effect modification to be elucidated in associations between occupational physical activity and health outcomes is sex. ${ }^{37}$ Although we found differences in BMI gain by sex, we observed no effect modification of the associations by sex. Fourth, we used measured weight and height to calculate BMI as our outcome, which are more valid than self-reported weight and height, ${ }^{24}$ likely influenced by social desirability bias. Finally, the efforts to recruit representative samples and the high attendance in the Tromsø Study surveys indicate high representability of the population. ${ }^{18}$

\section{Limitations}

We categorised self-reported physical activity into crude groups, which have introduced misclassification, as described previously. Thus, we may have missed potential energy expenditure changes deriving from physical activity that could influence energy balance. However, crude groups of self-reported physical activity are valuable for categorisation of population levels of physical activity, ${ }^{38}$ and the SGPALS categorisations have previously shown associations with multiple health outcomes, suggesting predictive validity of the instrument. ${ }^{20}$ Moreover, our findings were unaltered when occupational physical activity change was categorised into six groups.

The recall and social desirability bias associated with selfreported physical activity likely results in over-reporting of physical activity levels ${ }^{39}$ which is also demonstrated in office workers. ${ }^{40}$ Over-reporting of physical activity underestimates or overestimates the effect magnitude between physical activity and health outcomes. ${ }^{4}$ However, self-reported physical activity is currently the only instrument available in long-term ongoing cohort studies. ${ }^{4}$ Finally, as we did not adjust our models for energy intake and full-time/part-time work due to unavailable data, our results may be influenced by residual confounding.

\section{CONCLUSION}

We observed no association between changes in occupational physical activity and subsequent changes in BMI. Our findings do not support the hypothesis that occupational physical activity declines contributed to population gains in BMI over the past decades. Public health initiatives aimed at weight gain prevention may have greater success if focusing on other aspects than occupational physical activity.

\section{Author affiliations}

${ }^{1}$ School of Sport Sciences, Faculty of Health Sciences, UiT The Arctic University of Norway, Tromsø, Troms, Norway

${ }^{2}$ Department of Sports Medicine, Norwegian School of Sports Sciences, Oslo, Oslo, Norway

${ }^{3}$ Department of Chronic Diseases and Ageing, Norwegian Institute of Public Health, Oslo, Oslo, Norway

${ }^{4}$ Department of Community Medicine, Faculty of Health Sciences, UiT The Arctic University of Norway, Tromsø, Troms, Norway

${ }^{5}$ Department of Neuromedicine and Movement Science, Faculty of Medicine and Health Sciences, Norwegian University of Science and Technology, Trondheim, Trondelag, Norway

${ }^{6}$ Unicare Helsefort Rehabilitation Centre, Rissa, Trøndelag, Norway

${ }^{7}$ Centre for Sami Health Research, Department of Community Medicine, Faculty of

Health Sciences, UiT The Arctic University of Norway, Tromsø, Troms, Norway

Twitter Edvard H Sagelv @edvardhsagelv, UlfEkelund @Ulf_Ekelund, Laila A Hopstock@lailahopstock, Marius Steiro Fimland @mariusfimland and Bente Morseth @MorsethBente

Contributors EHS, BM, UE and LAH designed the study; EHS carried out statistical analyses; OL and TW provided statistical expertise; EHS drafted the manuscript; all authors interpreted the study results and contributed with manuscript revisions and approved the final version of the manuscript.

Funding The work of EHS is funded by Population Studies in the High North (Befolkningsundersøkelser i Nord: BiN), an internally funded project by UiT The Arctic University of Norway (no grant/award number). The remaining authors are funded by their respective positions/tenures.

Competing interests None declared.

Patient consent for publication Not required.

Ethics approval All participants in Tromsø 4-7 provided written informed consent, and the present study was approved by the Regional Ethics Committee for Medical Research (ref. 2016/758410)

Provenance and peer review Not commissioned; externally peer reviewed.

Data availability statement Data may be obtained from a third party and are not publicly available. The data that support the findings of this study are available 
from the Tromsø Study, but restrictions apply to the availability of these data, which were used under licence for the current study, and so are not publicly available. The data can be made available from the Tromsø Study upon application to the Data and Publication Committee for the Tromsø Study (see www.tromsostudy.com).

Supplemental material This content has been supplied by the author(s). It has not been vetted by BMJ Publishing Group Limited (BMJ) and may not have been peer-reviewed. Any opinions or recommendations discussed are solely those of the author(s) and are not endorsed by BMJ. BMJ disclaims all liability and responsibility arising from any reliance placed on the content. Where the content includes any translated material, BMJ does not warrant the accuracy and reliability of the translations (including but not limited to local regulations, clinical guidelines, terminology, drug names and drug dosages), and is not responsible for any error and/or omissions arising from translation and adaptation or otherwise.

\section{ORCID iD}

Edvard H Sagelv http://orcid.org/0000-0003-2213-5806

\section{REFERENCES}

1 Hill JO, Wyatt HR, Peters JC. Energy balance and obesity. Circulation 2012:126:126-32.

2 Romieu I, Dossus L, Barquera S, et al. Energy balance and obesity: what are the main drivers? Cancer Causes Control 2017;28:247-58.

3 Church TS, Thomas DM, Tudor-Locke C, et al. Trends over 5 decades in U.S. occupationrelated physical activity and their associations with obesity. PLoS One 2011;6:e19657.

4 Jones PR, Ekelund U. Physical activity in the prevention of weight gain: the impact of measurement and interpretation of associations. Curr Obes Rep 2019;8:66-76.

5 Jakicic JM, Powell KE, Campbell WW, et al. Physical activity and the prevention of weight gain in adults: a systematic review. Med Sci Sports Exerc 2019;51:1262-9.

$6 \mathrm{Ng} \mathrm{SW}$, Popkin BM. Time use and physical activity: a shift away from movement across the globe. Obes Rev 2012;13:659-80.

7 Knuth AG, Hallal PC. Temporal trends in physical activity: a systematic review. J Phys Act Health 2009;6:548-59.

8 Borodulin K, Harald K, Jousilahti P, et al. Time trends in physical activity from 1982 to 2012 in Finland. Scand J Med Sci Sports 2016;26:93-100.

9 Stamatakis E, Ekelund U, Wareham NJ. Temporal trends in physical activity in England: the health survey for England 1991 to 2004. Prev Med 2007;45:416-23.

10 Morseth B, Hopstock LA. Time trends in physical activity in the Tromsø study: an update. PLoS One 2020;15:e0231581.

11 Sarma S, Zaric GS, Campbell MK, et al. The effect of physical activity on adult obesity: evidence from the Canadian NPHS panel. Econ Hum Biol 2014;14:1-21.

12 Adair LS, Gultiano S, Suchindran C. 20-Year trends in Filipino women's weight reflect substantial secular and age effects. J Nutr 2011;141:667-73.

13 Colchero MA, Caballero B, Bishai D. The effect of income and occupation on body mass index among women in the Cebu longitudinal health and nutrition surveys (1983-2002). Soc Sci Med 2008;66:1967-78

14 Parkes KR. Demographic and lifestyle predictors of body mass index among offshore oil industry workers: cross-sectional and longitudinal findings. Occup Med 2003;53:213-21.

15 Bell AC, Ge K, Popkin BM. Weight gain and its predictors in Chinese adults. Int J Obes 2001;25:1079-86.

16 Wilsgaard T, Jacobsen BK, Arnesen E. Determining lifestyle correlates of body mass index using multilevel analyses: the Tromsø study, 1979-2001. Am J Epidemiol 2005; 162:1179-88.

17 Cornelio Cl, García M, Schiaffino A, et al. Changes in leisure time and occupational physical activity over 8 years: the Cornellè health interview survey follow-up study. J Epidemiol Community Health 2008:62:239-44.

18 Jacobsen BK, Eggen AE, Mathiesen EB, et al. Cohort profile: the Tromsø study. Int J Epidemiol 2012;41:961-7.
19 Saltin B, Grimby G. Physiological analysis of middle-aged and old former athletes. Comparison with still active athletes of the same ages. Circulation 1968;38:1104-15.

20 Grimby G, Börjesson M, Jonsdottir IH, et al. The "Saltin-Grimby Physical Activity Level Scale" and its application to health research. Scand J Med Sci Sports 2015;25 Suppl 4: :119-25.

21 Batty D. Reliability of a physical activity questionnaire in middle-aged men. Public Health 2000;114:474-6.

22 Matthiessen J, Biltoft-Jensen A, Rasmussen LB, et al. Comparison of the Danish physical activity questionnaire with a validated position and motion instrument. Eur J Epidemiol 2008;23:311-22.

23 Dobson KG, Gilbert-Ouimet M, Mustard C, et al. Body mass index trajectories among the Canadian workforce and their association with work environment trajectories over 17 years. Occup Environ Med 2020;77:374-80.

24 Maukonen M, Männistö S, Tolonen H. A comparison of measured versus self-reported anthropometrics for assessing obesity in adults: a literature review. Scand J Public Health 2018;46:565-79.

25 Hill JO, Wyatt HR, Reed GW, et al. Obesity and the environment: where do we go from here? Science 2003;299:853-5.

26 Swinburn B, Sacks G, Ravussin E. Increased food energy supply is more than sufficient to explain the US epidemic of obesity. Am J Clin Nutr 2009;90:1453-6.

27 Bull FC, Al-Ansari SS, Biddle S, et al. World Health Organization 2020 guidelines on physical activity and sedentary behaviour. Br J Sports Med 2020;54:1451-62.

28 Guthold R, Stevens GA, Riley LM, et al. Worldwide trends in insufficient physical activity from 2001 to 2016: a pooled analysis of 358 population-based surveys with 1.9 million participants. Lancet Glob Health 2018;6:e1077-86.

29 Swift DL, Johannsen NM, Lavie CJ, et al. The role of exercise and physical activity in weight loss and maintenance. Prog Cardiovasc Dis 2014;56:441-7.

30 Jørgensen K. Permissible loads based on energy expenditure measurements. Ergonomics 1985;28:365-9.

31 Saeidifard F, Medina-Inojosa JR, Supervia M, et al. Differences of energy expenditure while sitting versus standing: a systematic review and meta-analysis. Eur J Prev Cardiol 2018:25:522-38.

32 Santos R, Aires L, Santos P, et al. Prevalence of overweight and obesity in a Portuguese sample of adults: results from the Azorean physical activity and health study. Am J Hum Biol 2008;20:78-85.

33 Meseguer CM, Galán I, Herruzo R, et al. Trends in leisure time and occupational physical activity in the Madrid region, 1995-2008. Rev Esp Cardiol 2011;64:21-7.

34 Sofi F, Capalbo A, Marcucci R, et al. Leisure time but not occupational physical activity significantly affects cardiovascular risk factors in an adult population. Eur J Clin Invest 2007;37:947-53.

35 Richmond RC, Davey Smith G, Ness AR, et al. Assessing causality in the association between child adiposity and physical activity levels: a Mendelian randomization analysis. PLoS Med 2014;11:e1001618.

36 NCD Risk Factor Collaboration (NCD-RisC). Trends in adult body-mass index in 200 countries from 1975 to 2014: a pooled analysis of 1698 population-based measurement studies with 19.2 million participants. Lancet 2016;387:1377-96.

37 Coenen $\mathrm{P}$, Huysmans MA, Holtermann A, et al. Towards a better understanding of the 'physical activity paradox': the need for a research agenda. Br J Sports Med 2020;54:1055-7.

38 Shephard RJ. Limits to the measurement of habitual physical activity by questionnaires. Br J Sports Med 2003:37:197-206.

39 Helmerhorst HJF, Brage S, Warren J, et al. A systematic review of reliability and objective criterion-related validity of physical activity questionnaires. Int J Behav Nutr Phys Act 2012;9:103.

40 Wick K, Faude 0, Schwager S, et al. Deviation between self-reported and measured occupational physical activity levels in office employees: effects of age and body composition. Int Arch Occup Environ Health 2016;89:575-82. 